\title{
Requirements Effectiveness to Obtain License C (SIM) in Pressing of Traffic Accidents
}

\section{Sarpan*) and Sri Kusriyah $^{* *}$}

*) Student of Master of Law, Faculty of Law, Universitas Islam Sultan Agung (UNISSULA) Semarang, E-mail: 123sarpanwsb@gmail.com

**) Faculty of Islamic Religion, Universitas Islam Sultan Agung

\begin{abstract}
.
This study aims to determine and analyze the effectiveness of reducing traffic accidents in Purworejo by encouraging children aged 17 years to have a license $C$, and to reduce traffic accidents seen from Article 81 paragraph (2) letter A of Act No. 2 Of 2009. Methods approach used in this study is a sociological juridical approach. The research specification is descriptive analytical. In this research, the analysis used is qualitative analysis. The results of this study are: 1) The effectiveness of the 17 year age setting as a condition of obtaining a Class $C$ Driving License (SIM C) in order to reduce traffic accidents in Purworejo has been effective, because teenagers who have a license $C$ can better understand the procedures for driving a motorized vehicle on the highway and obey more traffic rules. According to the examiner, the age limit of 17 years to obtain a license $C$ is not suitable in order to reduce traffic accidents. There is no need to change the age limit of 17 years, only to be tightened in testing the license so that the quality of the license better reflects the driver's competence. 2) The role of the police in reducing traffic accidents, seen from Article 81 Paragraph 2 Letter A of Act No. 22 of 2009, is sufficiently good in its implementation and ideal as well as the application of sanctions given to perpetrators of road accidents on a regular basis.

Keywords: Effectiveness, license Class C, Accident, Traffic, Highway.
\end{abstract}

\section{Introduction}

A driving license is proof of the legitimacy of competence, control devices, and police forensic data for someone who has passed the test of knowledge, ability and skills to drive a motorized vehicle on the road in accordance with the requirements determined under the Road Traffic and Transportation Law ${ }^{1}$.

As stipulated in Article 77 of Act No. 22 of 2009, a driving license (SIM) can be classified according to the type of motorized vehicle being driven. Article 80 letter $\mathrm{d}$ states that a driving license is valid for driving a motorcycle. Class $\mathrm{C}$ license is a license to drive a two-wheeled motorized vehicle designed with a speed of more than $40 \mathrm{~km} /$ hour. $^{2}$

The requirements for making a license have been specified in Act No. 22 of 2009 concerning Road Traffic and Transportation as stipulated in Article 81 paragraph (1) which states that in order to obtain a driver's license, everyone must

\footnotetext{
1Sovia Hasanah, 2 June 2017, "The Legal Basis for International SIM", https://www.hukumonline.com/klinik/detail/ulasan/lt592e221b26fc2/dasar-hukum-siminternasional/ Retrieved August 15, 2020.

${ }^{2}$ Des Suryani, Ana Yulianti, Muhammad Zulhelmi, "Aplikasi Legalitas Surat Izin Mengemudi (SIM) Berbasis Mobile (Studi Kasus : Polisi Resort Rengat)", IT Journal Research and Development, Vol. 2, No. 2 (2018), hlm. 37. url : https://journal.uir.ac.id/index.php/ITJRD/article/view/1105
} 
meet the age, administrative, health requirements and pass an exam. The age requirement in making a driving license is specified in Article 81 paragraph (2) letter a, especially for license $\mathrm{C}$ is 17 (seventeen). Furthermore, the administrative requirements are stipulated in Article 81 paragraph (3), namely having an identity in the form of an Identity Card (ID), filling out an application form and formulating a fingerprint.

The regulation was made by meeting the compromising elements of various interests in society and various other aspects. With the hope, those who already have a license can comply with traffic signs so that they can reduce traffic accidents. However, it turns out that in the field, the license from the police has not been proven to be effective in minimizing the accident rate. Traffic accidents are still common, especially at a young age.

The phenomenon of traffic accidents at a young age can be said to be a teenager, but it is undeniable that emotionally and psychologically the teenager is still very unstable, because the person concerned is looking for an identity and is easily influenced by the surrounding conditions and at that age is usually impatient, less ethical, and tend not to pay attention to traffic rules on the road ${ }^{3}$. The following is the age data of the perpetrators of traffic accidents in Purworejo Regency:

Table 1

Data on the age of the perpetrators of the Traffic accident in Purworejo in 2018-2020

\begin{tabular}{lllll}
\hline No. & Age group & 2018 & 2019 & 2020 \\
\hline 1 & $0-15$ years & 39 & 33 & 15 \\
\hline 2 & $16-30$ years & 186 & 202 & 110 \\
\hline 3 & $31-40$ years & 66 & 82 & 60 \\
\hline 4 & $41-50$ Years & 75 & 94 & 52 \\
\hline 5 & $>51$ Years & 89 & 132 & 64 \\
\hline
\end{tabular}

Source: Data from Purworejo Police, 2020

Based on the table, it can be seen that for the last 3 (three) years, traffic accidents have been dominated by young actors aged 16-30 years. Traffic accidents at a young age are a consequence of technological advances. Various efforts are needed to improve this situation, including supervision by parents of their children; tightening regulations in the process of making a Driving License; as well as education about driving safety from an early age.

\section{Research methods}

The approach method used in this study is a sociological juridical approach. The research specification is descriptive analytical. Types and sources of data can be divided into two, namely primary data and secondary data. Data obtained in the facts of community life or field data sourced from the Purworejo Police. Secondary data in

\footnotetext{
${ }^{3}$ Soerjono, Soekanto. (2015). Sosiologi Suatu Pengantar. Jakarta: PT. Rajawali Press. p.60
} 
this study are in the form of primary legal materials, secondary legal materials, and tertiary legal materials. Data collection methods in this study are: interviews and literature study. Furthermore, the analysis used in this research is qualitative.

\section{Results and Discussion}

\subsection{The Effectiveness of Aging 17 Years as a Requirement for Obtaining a Class C Driving License (SIM C) in Order to Reduce Traffic Accidents in Purworejo}

Basically, effectiveness is the level of success in achieving goals. Phenomena that occur at the present time make the law considered unable to fully provide a sense of security, justice, and create legal concern. It needs to be examined carefully. From this phenomenon then raises expectations that the law can be affirmed upright and consistently, because legal uncertainty and a decline in legal authority will give birth to a legal crisis.

Furthermore, according to Mastra Liba there are 12 (fourteen) factors that affect the performance of law enforcement, namely: 1) The state administration system that places the attorney general on a par with the minister; 2) The system in legislation is inadequate; 3) Human resource factors; 4) There are factors of interest inherent in the apparatus: personal interests, group interests, and state political interests; 5) Corspgeits in institutions; 6) There is strong pressure on law enforcement officials; 7) Cultural, religious, and leadership factors; 8) The legislature as a legislative body needs to optimally support and set good examples in law enforcement in Indonesia; 9) The political will of the government; 10) Organize crime networks; 11) The influence of collusion in the spirit of law enforcement officers; 4

The statement from the Head of Sub-Department of the Purworejo Police, namely AKP Dani Kurniawan, SE, SIK that: ${ }^{5}$ Traffic violations that are often found include minors who drive vehicles, do not wear SNI helmets, do not turn on the headlights, violations of motor vehicle signs and equipment".

The same statement was also stated by Briptu Robi Irawan as a member of the Purworejo Traffic Police that traffic violations that are often committed by teenagers in Purworejo Regency are not having a driver's license, not carrying a STNK, not wearing a helmet, and racing exhaust. ${ }^{6}$

Aiptu Tukul Puji Puriyono, $\mathrm{SH}, \mathrm{MH}$ as the examiner for license then the Purworejo Police also stated that: "Violations that are mostly committed by teenagers or "children" in the district. Purworejo mostly is driving a vehicle on the highway before having a driving license (SIM) and violating signposts, warning and prohibitions on the road."

\footnotetext{
${ }^{4}$ Yulia, Rena (2010). Viktimologi (Pelindungan Hukum Terhadap Korban Kejahatan). Yogyakarta.Graha Ilmu. P.85

Interview with AKP Dani Kurniawan, SE, SIK as Head of Traffic Unit of the Purworejo Police on August 18, 2020

6Interview with Briptu Robi Irawan as a member of the Purworejo Traffic Police on August 18, 2020
} 
Based on interview above, there are many violations that are often committed by teenagers in Purworejo, one of which is driving a motorized vehicle without having a driving license because they are not old enough to own it. So far, without realizing it, every motorized vehicle owner's license is indispensable. But not everyone obeys these rules. Most of them do not know about the requirements for license ownership as stipulated in Article 81 of the Road Traffic and Transportation Law, namely submit a written application, can read and write, have sufficient knowledge of Road Traffic and Transportation (LLAJ) and the basic technicalities of motorized vehicles and the age limit for motorcyclists is 17 years old.

Briptu Robi Irawan as a member of the Purworejo Traffic Police revealed that the requirements for obtaining a license $C$, namely 17 years old, are effective in reducing traffic accidents in Purworejo Regency, because teenagers who have license $\mathrm{C}$ can better understand the procedures for driving a motorized vehicle on the highway and more obey traffic rules. ${ }^{7}$

Based on Act No. 22 of 2009 concerning Traffic and Road Transportation in Article 81 paragraph 1 there are requirements for obtaining a SIM, where there are 4 requirements for a person to obtain a driving license, namely:

- Age Requirements, where in license A, C and D the minimum requirement is 17 years old, for license BI the minimum requirement is 20 years and for license B II the minimum requirement is 21 years.

- Administrative Requirements, in the process of making a SIM, administrative requirements in the form of ID, filling out forms and formulation of fingerprints are required.

- Requirements for passing the exam by taking three stages of the exam, namely:

- The theory test, where the applicant takes a written exam related to the theory of traffic rules and traffic regulations by using a computer and in person

- Practice Test, is a test where the license applicant practices proficiency in using the vehicle he owns, according to the license class he wants to get.

- Simulator test, is a test using a vehicle replica equipped with a computerized test system using a simulator only for general license applicants

Age 17 years is a teenager, an age that is vulnerable to the influence of culture and the surrounding environment so that it can affect thought patterns, emotionally, and intellectually. Moreover, at these ages, most of the school children are required to have their intellectual intelligence in school. Most 17 year olds are less able to control emotion, especially when on the road. But the fact is that most of the road users on the road are teenagers. So that according to the examiner, the age limit of 17 years to obtain a license $C$ is not suitable in order to reduce traffic accidents. There is no need for changes to the age limit of 17 years, only to be tightened in testing the license so that the quality of the license better reflects the competence of the driver. ${ }^{8}$

According to the author setting the age of 17 years as a condition for obtaining a Class C Driving Permit (SIM C) in order to reduce traffic accidents in Purworejo,

${ }^{7}$ Ibid.

8Interview with Aiptu Tukul Puji Puriyono, SH, MH as the examiner for SIM Sat then at Purworejo Police on 19 August 2020 
seen from the theory of the effectiveness of the law, it has been running effectively but there are still teenagers or minors who drive motorized vehicles in the Purworejo area. In regulating effectiveness, it is not the fault of law enforcement alone, but also from social factors. Romli Atmasasmita, who stated that the effectiveness of law is where applicable laws can be obeyed and have an influence in carrying out social engineering, not only because of the mental attitude of law enforcement officers but also lies in the factor of good legal socialization. ${ }^{9}$

In addition, the effectiveness of a statutory regulation often experiences obstacles, these constraints are influenced by several factors, among others ${ }^{10}$ laws and regulations factors, law enforcement factors, facilities or facilities factors, community factors, and cultural factors. These factors also affect the effectiveness of regulating 17 years of age as a requirement for obtaining a Class $C$ Driving License (SIM C) in order to reduce traffic accidents in Purworejo, namely factors of legislation, law enforcement factors, community factors, and cultural factors.

\subsection{The Role of Police to Reduce Traffic Accidents Judging from Article 81 Paragraph 2 Letter A of Act No. 22 of 2009}

The role of the Purworejo Police Traffic Unit in overcoming the high rate of traffic accidents on the highway for motorists who do not have a license because they are not old enough or not yet 17 years of age, the implementation is good enough and ideal and the application of sanctions given to perpetrators of road accidents has regular.

Aiptu Tukul Puji Puriyono, $\mathrm{SH}, \mathrm{MH}$ as the examiner for license Sat Then Purworejo Police stated that the role of the police in enforcing the regulations of article 81 paragraph 2 letter A of Act No. 22 of 2009 is ${ }^{11}$

- Conducting outreach to the public regarding the requirements for 17 years of age to obtain license C, A and D.

- Implementing the issuance of license in accordance with the applicable mechanism so that the license function as the legitimacy of driving competence can truly be realized.

- Providing strict legal sanctions for people who commit traffic violations or traffic accidents so as to provide a deterrent effect.

The Head of Traffic Center for the Purworejo Police, AKP Dani Kurniawan, SE, SIK also added a statement that the role as Kasatlantas in reducing traffic accidents seen from article 81 paragraph 2 letter A of Act No. 22 Of 2009 is to supervise and control the implementation of the issuance of a Driving License so that implemented in accordance with the provisions stipulated by Law and Perkap No. 9 of 2012 with the aim of issuing a license to obtain good driving competence. ${ }^{12}$

However, in carrying out its role for reducing traffic accidents the police are sometimes also hampered by several things, as stated by the Head of the Traffic

\footnotetext{
${ }_{9}^{9}$ Atmasasmita, Romli. (2001). Reformasi Hukum, Hak Asasi Manusia dan. Penegakan Hukum. Bandung: Mandar Maju. p.55

${ }^{10}$ Soekanto, Soerjono. (2008). Pengantar Penelitian Hukum. Jakarta: UI Press. p.58

11 Op.Cit.

12 Interview with AKP Dani Kurniawan, SE, SIK as Head of Traffic Unit of the Purworejo Police on August 18, 2020
} 
Unit for the Purworejo Police, namely AKP Dani Kurniawan, SE, SIK, that obstacles in order to reduce traffic accidents among teenagers, including:

- The mindset of youth, especially in Purworejo, is that it is "cool" if you have a vehicle and can drive on the highway

- Teenagers do not like public transportation as a mode of mass transportation

- Parents who are proud or happy to see their children grow into adolescence and then be rewarded with motorbikes.

- The police did not respond to socialization from the police.

- Less maximal law enforcement of traffic (many sanctions and reconciliation of the parties involved in traffic accidents)

In addition, in taking action against adolescents who drive motorized vehicles and do not yet have a Purworejo Satlantas SIM, they try to take action against violations committed by teenagers and do not have a license with verbal, written or TILANG warnings. In addition, the Satlantas Dikyasa Unit is intensely carrying out socialization to adolescents in schools so that the implementation of the Traffic Law and road transportation can be carried out properly, including the obligation to have a license for teenagers who drive motorized vehicles on the highway. ${ }^{13}$

Based on these obstacles, the Purworejo Police Traffic Head also stated that the efforts made by the Purworejo Traffic Police in overcoming these obstacles were in the form of providing orderly traffic education to various circles, giving parents the commitment to allow their children to drive vehicles at least 17 years of age, using safe mass comfortable transportation and firm in law enforcement against traffic violations and accidents.

The role of the police in reducing traffic accidents in implementing Article 81 Paragraph 2 Letter A of Act No. 22 Of 2009 is seen from the theory of law enforcement that the implementation is good and ideal and the application of sanctions given to perpetrators of road accidents is regular. Soerjono Soekanto, who said that law enforcement is an activity to harmonize the relationship of values that are described in solid principles and attitudes as a series of final value definitions, to create, maintain and maintain social peace. ${ }^{14}$

The role of the police in enforcing the regulation of article 81 paragraph 2 letter A of Act No. 22 Of 2009 is in the form of disseminating information to the public regarding the requirements for 17 years of age to obtain a license $\mathrm{C}$. In principle, the law enforcement process still refers to the basic values contained in law, such as justice (gerechtigheit), legal certainty (rechtssicherheit), and legal benefit (zweckmassigkeit), these three elements must be fulfilled in the law enforcement process as well as being the main objective of law enforcement ${ }^{15}$. It is clear that in this case the role of the police in terms of law enforcement is very important in disseminating laws and regulations.

\section{Conclusion}

\footnotetext{
13 Ibid.

${ }^{14}$ Soekanto, Soerjono. (2007). Faktor-Faktor Yang Mempengaruhi Penegakan Hukum. Raja Jakarta: Grafindo Endasa. p.35

${ }^{15}$ Mertokusumo, Sudikno. (2003). Mengenal Hukum: Suatu Pengantar. Yogyakarta: Liberty. p.122
} 
Based on the results of the research and discussion above, it is concluded that the effectiveness of the 17 year age setting as a condition of obtaining a Class $\mathrm{C}$ Driving License (SIM C) in order to reduce traffic accidents in Purworejo has been effective, because teenagers who have license $C$ can better understand the procedures for driving a vehicle on the highway and obey more traffic regulations. The role of the police in reducing traffic accidents, seen from Article 81 Paragraph 2 Letter A of Act No. 22 Of 2009, is sufficiently well implemented and ideal and the application of sanctions given to perpetrators of road accidents is regular.

\section{References}

\section{Journal:}

[1] Des Suryani, Ana Yulianti, Muhammad Zulhelmi, "Aplikasi Legalitas Surat Izin Mengemudi (SIM) Berbasis Mobile (Studi Kasus : Polisi Resort Rengat)", IT Journal Research and Development, Vol. 2, No. 2 (2018), hlm. 37. url: https://journal.uir.ac.id/index.php/ITJRD/article/view/1105

\section{Books:}

[1] Atmasasmita, Romli. (2001). Reformasi Hukum, Hak Asasi Manusia dan. Penegakan Hukum. Bandung: Mandar Maju

[2] Mertokusumo, Sudikno. (2003). Mengenal Hukum: Suatu Pengantar. Yogyakarta: Liberty

[3] Soekanto, Soerjono. (2007). Faktor-Faktor Yang Mempengaruhi Penegakan Hukum. Raja Jakarta: Grafindo Endasa

[4] Soekanto, Soerjono. (2008). Pengantar Penelitian Hukum. Jakarta: UI Press

[5] Soerjono, Soekanto. (2015). Sosiologi Suatu Pengantar. Jakarta: PT. Rajawali Press

[6] Yulia, Rena (2010). Viktimologi (Pelindungan Hukum Terhadap Korban Kejahatan). Yogyakarta.Graha Ilmu

\section{Internet:}

[1] Sovia Hasanah, 2 June 2017, "The Legal Basis for International SIM", https://www.hukumonline.com/klinik/detail/ulasan/lt592e221b26fc2/dasarhukum-sim-internasional/ Retrieved August 15, 2020.

\section{Interview:}

[1] Interview with Aiptu Tukul Puji Puriyono, $\mathrm{SH}, \mathrm{MH}$ as the examiner for license Sat then at Purworejo Police on 19 August 2020

[2] Interview with AKP Dani Kurniawan, SE, SIK as Head of Traffic Unit of the Purworejo Police on August 18, 2020

[3] Interview with Briptu Robi Irawan as a member of the Purworejo Traffic Police on August 18, 2020 